DOI 10.22460/jpmi.v1i3.409-414

\title{
ANALISIS KEMAMPUAN PENALARAN MATEMATIS SISWA SMA PADA MATERI LIMIT FUNGSI
}

\author{
Bentang Indria Yusdiana ${ }^{1}$,Wahyu Hidayat ${ }^{2}$ \\ ${ }^{1,2}$ IKIP Siliwangi, Jl. Terusan Jenderal Sudirman, Cimahi, Jawa Barat, Indonesia \\ ${ }^{1}$ bentangindri25@gmail.com, ${ }^{2}$ wahyu@ikipsiliwangi.ac.id \\ Diterima: 23 April 2018; Disetujui: 28 Mei 2018
}

\begin{abstract}
This research is a qualitative descriptive research that aims to analyze the level of students' reasoning ability in solving the problem on material function limit by categorizing high, medium, and low mathematical reasoning ability. The subjects of the study were 20 students of class XII. A form of data retrieval is the provision of 4 items about written tests and interviews on selected subjects. Based on the results of the analysis, the average value of the whole matter of the instrument of mathematical reasoning ability derives $89 \%$ for the indicator performing calculations based on the applicable mathematical formula or rules, $84 \%$ and $64 \%$ of the indicators draw conclusions and $93 \%$ for the indicator to make the estimate so that if totaled and averaged $83 \%$. Then the mathematical reasoning ability of high school students of class XII is appertaining high.
\end{abstract}

Keywords: Mathematical Reasoning, Function Limit

\begin{abstract}
Abstrak
Penelitian ini merupakan penelitian deskriptif kualitatif yang bertujuan untuk menganalisis tingkat kemampuan penalaran siswa dalam menyelesaikan permasalahan pada materi limit fungsi dengan pengkatagorian tingkat kemampuan penalaran matematis tinggi, sedang, dan rendah. Subjek penelitian adalah siswa kelas XII sebanyak 20 orang. Bentuk pengambilan data yaitu pemberian 4 butir soal tes tertulis dan wawancara pada subjek terpilih. Berdasarkan hasil analisis, nilai rata-rata dari keseluruhan soal instrumen kemampuan penalaran matematis memperoleh $89 \%$ untuk indikator melaksanakan perhitungan berdasarkan rumus atau aturan matematika yang berlaku, $84 \%$ dan $64 \%$ untuk indikator menarik kesimpulan dan $93 \%$ untuk indikator membuat perkiraan sehingga jika ditotal dan dirataratakan mencapai 83\%. Maka kemampuan penalaran matematis siswa SMA kelas XII tergolong tinggi.
\end{abstract}

Kata Kunci: Penalaran Matematis, Limit Fungsi

How to cite: Yusdiana, B. I., \& Hidayat, W. (2018). Analisis Kemampuan Penalaran Matematis Siswa SMA pada Materi Limit Fungsi. JPMI - Jurnal Pembelajaran Matematika Inovatif, 1 (3), 409-414.

\section{PENDAHULUAN}

Pendidikan adalah usaha sadar yang sengaja dirancang untuk mencapai tujuan yang telah ditetapkan. Pendidikan bertujuan untuk meningkatkan kualitas sumber daya manusia. Pendidikan merupakan salah satu cara pembentukan kemampuan manusia untuk menggunakan rasional sebagai jawaban dalam menghadapi masalah-masalah yang timbul dalam usaha menciptakan masa depan yang baik. 
Matematika sebagai salah satu mata pelajaran di sekolah dinilai sangat memegang peranan penting karena matematika dapat meningkatkan pengetahuan siswa dalam berpikir secara logis, rasional, kritis, cermat, efektif, dan efisien. Oleh karena itu, pengetahuan matematika harus dikuasai sedini mungkin oleh para siswa. Menurut Isnaeni, Fajriyah, Risky, Purwasih, \& Hidayat, (2018) pendidikan matematika dapat mendorong masyarakat untuk selalu maju, terbukti dengan adanya perkembangan teknologi modern. Oleh karena itu, belajar matematika denganbaik merupakan langkah pertama dalam penguasaan konsep.

Dalam pengembangan penguasaan konsep, penalaran siswa sangat dibuuhkan untuk memberi arti dalam proses belajar mandiri (Hermawan \& Hidayat, 2018; Hidayat, 2017; Hidayat \& Prabawanto; 2018; Sholihat, Hidayat, \& Rohaeti, 2018). Menurut Basir, (2015) penalaran matematis dapat dijadikan fondasi dalam memahami dan doing matematika serta bagian integral dari pemecahan masalah. Penalaran berbeda dengan berpikir, penalaran matematika merupakan bagian terpenting dalam berpikir yang melibatkan pembentukan generalisasi dan menggambarkan konklusi yang valid tentang ide dan bagaimana kaitan antara ide-ide tersebut. Ario, (2016) menyatakan bahwa secara garis besar penalaran matematis dapat digolongkan pada dua jenis, yaitu penalaran induktif dan penalaran deduktif. Penalaran induktif adalah penalaran yang berdasarkan sejumlah kasus atau cntoh-contoh terbatas yang teramati. Penalaran deduktif adalah proses penalaran dari pengetahuan prinsip atau pengalaman umum yang menuntun kita kepada kesimpulan untuk suatu yang khusus Ramdani, (2012).

Berdasarkan pra survey peneliti melakukan wawancara dengan guru matematika disekolah tersebut didapat informasi bahwa kemampuan penalaran siswa dalam mempelajari matematika masih sangat rendah. Dalam proses pembelajaran masih menggunakan pembelajaran biasa, guru mendominasi dalam pembelajaran. Pada saat pembelajaran berlangsung hanya beberapa siswa saja yang aktif bertanya dan menjawab soal yang diberikan guru, siswa yang kurang aktif dalam proses pembelajaran cenderung mendengar dan mencatat yang disampaikan oleh guru sehingga pembelajaran hanya berjalan satu arah saja, sehingga dalam proses pembelajaran berlangsung kemampuan penalaran adaptif siswa masih belum terlihat. Pembelajaran yang berpusat pada guru tidak menempatkan siswa sebagai subjek didik yang menemukan pengetahuanya, melainkan sebagai objek yang harus disuapi pengetahuan, pendapat yang sama juga dikemukakan oleh Darhim, (1979) Sangat dibutuhkan pembelajaran yang tepat untuk mengakomodasi peningkatan kompetensi siswa sehingga hasil belajar dapat lebih baik khususnya kemampuan belajar matematika maupun mata pelajaran lainnya, namun sangat dibutuhkan setiap manusia disaat memecahkan masalah ataupun disaat menentukan keputusan.

Menurut Sumarmo, (2012) generalisasi menggambarkan sebagai inti dari pemikiran matematis, generalisasi dimulai ketika merasakan pola yang mendasari, bahkan jika anda tidak bisa membuat kesimpulan. Dalam membahas tentang penalaran, pentingnya proses conjecturing dan pentingnya bersedia untuk memodifikasi dugaan seseorang. Mendefinisikan dugaan sebagai menebak sadar, menekankan bahwa dugaan harus terbuka untuk perbaikan. Tujuan penelitian ini adalah untuk mendeskripsikan: (1) penalaran matematis siswa kemampuan tinggi dalam memecahkan masalah pada materi limit fungsi kelas XI, (2)penalaran matematis siswa kemampuan sedang dalam memecahkan masalah pada materi limit fungsi kelas XI, (3) penalaran matematis siswa kemampuan rendah dalam memecahkan masalah pada materi limit fungsi kelas XI. 


\section{METODE}

Penelitian ini tergolong dalam penelitian deskriptif kualitatif. Subjek dalam penelitian ini adalah siswa kelas XII di satu SMA Negeri Parompong Kabupaten Bandung Barat sebanyak 20 siswa. Ruang lingkup materi yang digunakan adalah materi Limit fungsi yang diajarkan di kelas XI. Penelitian ini menggunakan instrumen tes kemampuan penalaran matematis.

Dalam penelitian ini, indikator penalaran matematis yang digunakan dan aspek yang diteliti dapat dilihat pada tabel berikut ini:

Tabel 1. Kisi-kisi soal Kemampuan Penalaran Matematis

\begin{tabular}{cl}
\hline $\begin{array}{c}\text { Nomor } \\
\text { soal }\end{array}$ & \multicolumn{1}{c}{ Indikator Penalaran Matematis } \\
\hline 1 & $\begin{array}{l}\text { Melaksanakan perhitungan berdasarkan rumus/ aturan matematika yang } \\
\text { berlaku }\end{array}$ \\
2 & $\begin{array}{l}\text { Menarik kesimpulan umum berdasarkan proses/ konsep matematika } \\
\text { yang terlihat }\end{array}$ \\
3 & $\begin{array}{l}\text { Membuat perkiraan } \\
\text { Menarik kesimpulan berdasarkan keserupaan proses/ konsep matematika } \\
\text { yang terlihat }\end{array}$ \\
\hline
\end{tabular}

Penskoran terhadap kemampuan penalaran matematis digunakan rubik penilaian kemampuan penalaran matematis yang dikembangkan oleh Sulistiawati, Suryadi, \& Fatimah, (2015):

Tabel 2. Kriteria Penilaian Penalaran Matematis

\begin{tabular}{|c|c|}
\hline Skor & Kriteria \\
\hline 4 & Jawaban secara substansi benar dan lengkap \\
\hline 3 & Jawaban memuat satu kesalahan atau kelalaian yang signifikan \\
\hline 2 & $\begin{array}{l}\text { Sebagian jawaban benar dengan satu atau lebih kesalahan atau kelalaian } \\
\text { yang signifikan }\end{array}$ \\
\hline 1 & $\begin{array}{l}\text { Sebagai jawaban tidak lengkap tetapi paling tidak memuat satu argumen } \\
\text { yang benar }\end{array}$ \\
\hline 0 & $\begin{array}{l}\text { Jawaban tidak benar berdasarakan proses atau argumen, atau tidak ada } \\
\text { respon sama sekali }\end{array}$ \\
\hline
\end{tabular}

Tabel 3. Kategori Kemampuan Penalaran Matematis Siswa (Sulistiawati et al., 2015)

\begin{tabular}{cccccc}
\hline Kategori & \multicolumn{6}{c}{ Pencapaian Kemampuan Penalaran Matematis } \\
\hline Tinggi & & & $\mathrm{x}_{\mathrm{i}}$ & $>$ & $70 \%$ \\
Sedang & $55 \%$ & $<$ & $\mathrm{x}_{\mathrm{i}}$ & $<$ & $70 \%$ \\
Rendah & & $\mathrm{x}_{\mathrm{i}}$ & $\leq$ & $55 \%$ & \\
\hline
\end{tabular}

\section{HASIL DAN PEMBAHASAN}

Dari hasil tes tertulis terhadap 20 siswa menggunakan instrumen tes kemampuan penalaran matematik. Instrumen penilaian berupa tes kemampuan penalaran matematik sebanyak 4 soal uraian. Hasil penelitian ini yaitu data yang diperoleh dari analisis jawaban siswa berdasarkan 
acuan pedoman penskoran kemampuan penalaran matematis (Tabel 3). Hasil penskoran kemampuan penalaran matematik pada materi Limit Fungsi bagi Siswa SMA disajikan pada Tabel 4 berikut.

Tabel 4. Deskripsi skor kemampuan penalaran siswa dalam tiap indikator soal

\begin{tabular}{ccccccc}
\hline $\begin{array}{c}\text { NO } \\
\text { SOAL }\end{array}$ & N & MINIMUM & MAKSIMUM & RATA-RATA & PRESENTASE & SD \\
\hline 1 & 20 & 2 & 4 & 3,55 & 89 & 0,83 \\
2 & 20 & 0 & 4 & 3,35 & 84 & 1,23 \\
3 & 20 & 0 & 4 & 3,70 & 93 & 0,98 \\
4 & 20 & 0 & 4 & 2,75 & 69 & 1,65 \\
\hline
\end{tabular}

Persentase rata-rata kemampuan penalaran matematis kemampuan siswa dalam melaksanakan perhitungan berdasarkan rumus/ aturan matematika yang berlaku pada soal no 1 dengan persentase adalah $89 \%$, itu berarti sebagian besar siswa mampu melaksanakan perhitungan berdasarkan rumus/ aturan matematika yang berlaku, pada soal no 2 dan 4 persentase berturut turut yaitu $84 \%$ dan $69 \%$, itu berarti sebagian besar siswa mampu menarik kesimpulan berdasarkan keserupaan proses/ konsep matematika yang terlihat. Persentase rata-rata kemampuan penalaran matematis siswa dalam membuat perkiraan pada soal 3 adalah $93 \%$, itu berarti siswa mampu membuat perkiraan dengan pendekatan nilai limit yang tersedia.

Persentase rata-rata kemampuan penalaran matematis siswa dalam keseluruhan soal mencapai $83 \%$, itu berarti sebagian besar siswa SMA Negeri di Kabupaten bandung Barat tergolong kemampuan tinggi.

Berikut disajikan beberapa sampel jawaban siswa dalam menjawab pertanyaan yang meliputi indikator 1 sampai dengan 4.

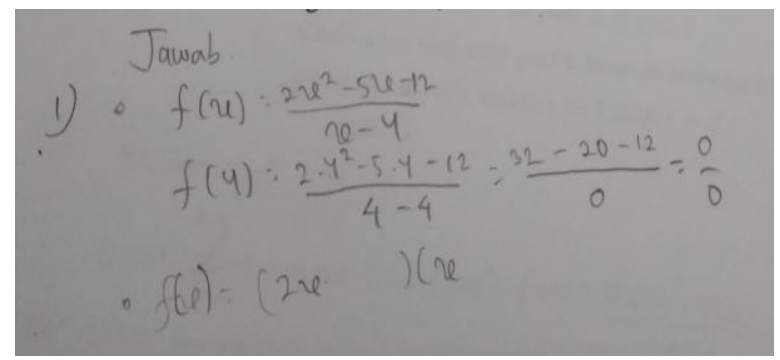

Gambar 1. Jawaban Siswa dalam menjawab pertanyaan indikator ke-1

Berdasarkan hasil wawancara siswa penyebab siswa tidak bisa menjawab indikator ke-1 Melaksanakan perhitungan berdasarkan rumus/ aturan matematika yang berlaku yaitu, lupa akan materi, bingung menentukan rumus, dan juga tidak mengerti pertanyaannya. 


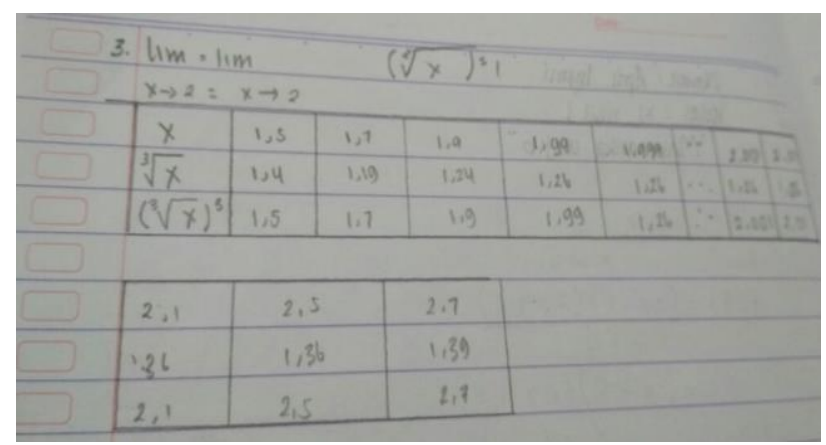

Gambar 2. Jawaban Siswa dalam menjawab pertanyaan indikator ke-2

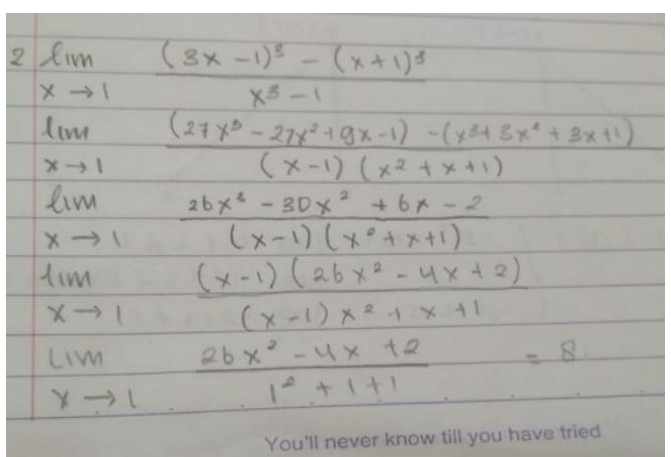

Gambar 3. Jawaban Siswa dalam menjawab pertanyaan indikator ke-3.

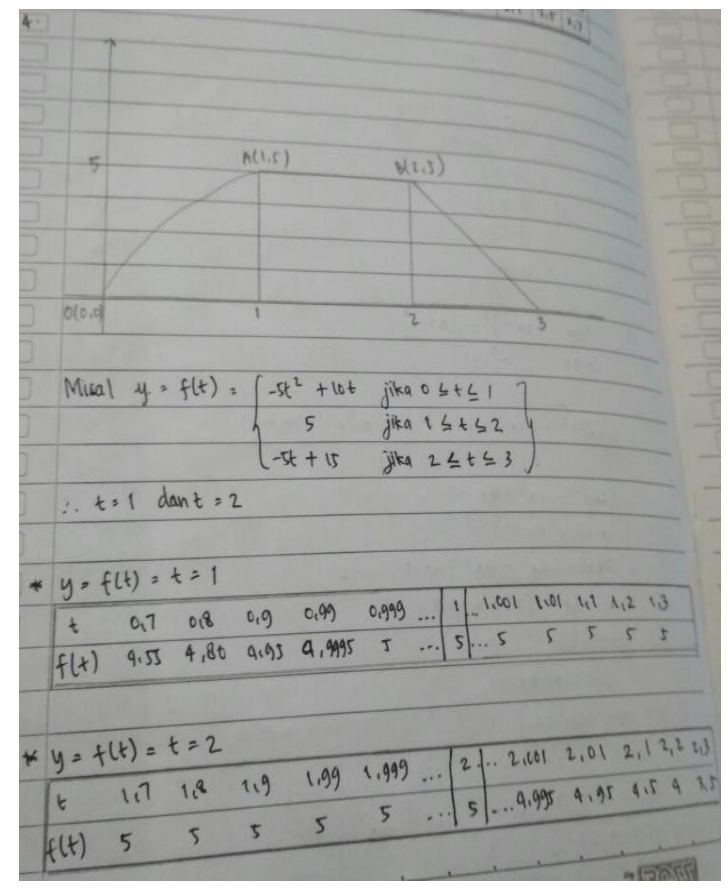

Gambar 4. Jawaban Siswa dalam menjawab pertanyaan indikator ke-4

Dari gambar 1 sampai dengan gambar 4 terlihat bahwa siswa dapat menyelesaikan permasalahan yang ada dalam soal nomor 2,3 , dan 4 dan dapat memenuhi indikator kemampuan penalaran matematis. 


\section{KESIMPULAN}

Berdasarkan hasil penelitian dan pembahasan yang telah diuraikan, maka dapat diambil kesimpulan bahwa Kemampuan penalaran siswa SMA pada materi Limit Fungsi termasuk dalam kategori tinggi. Hal ini dapat dilihat dari rata-rata siswa yang memiliki kemampuan penalaran sebesar 83\% Dari pengerjaan soal instrumen kemampuan penalaran dan soal- soal tersebut dikatakan baik untuk diuji cobakan pada siswa kelas XI.

\section{DAFTAR PUSTAKA}

Ario, M. (2016). Analisis Kemampuan Penalaran Matematis Siswa SMK Setelah Mengikuti Pembelajaran Berbasis Masalah. Jurnal Ilmiah Edu Research, 5(2), 125-134.

Basir, M. A. (2015). Masalah Matematis Ditinjau Dari Gaya Kognitif, 3, 106-114.

Darhim. (1979). PENGARUH PEMBELAJARAN MATEMATIKA KONTEKSTUAL TERHADAP SIKAP SISWA SEKOLAH DASAR. FPMIPA Universitas Pendidikan Indonesia, 1-13.

Hermawan, A. S., \& Hidayat, W. (2018). Meningkatkan Kemampuan Penalaran Matematik Siswa SMP Melalui Pendekatan Penemuan Terbimbing. JPMI (Jurnal Pembelajaran Matematika Inovatif), 1(1), 7-20.

Hidayat, W. (2017). Adversity Quotient dan Penalaran Kreatif Matematis Siswa SMA dalam Pembelajaran Argument Driven Inquiry pada Materi Turunan Fungsi. KALAMATIKA Jurnal Pendidikan Matematika, 2(1), 15-28.

Hidayat, W., \& Prabawanto, S. (2018, January). Improving students' creative mathematical reasoning ability students through adversity quotient and argument driven inquiry learning. In Journal of Physics: Conference Series (Vol. 948, No. 1, p. 012005). IOP Publishing.

Isnaeni, S., Fajriyah, L., Risky, E. S., Purwasih, R., \& Hidayat, W. (2018). Analisis Kemampuan Penalaran Matematis dan Kemandirian Belajar Siswa SMP pada Materi Persamaan Garis Lurus. Journal of Medives, 2(1), 107-116.

Ramdani, Y. (2012). Pengembangan Instrumen dan Bahan Ajar untuk Meningkatkan Kemampuan Komunikasi, Penalaran, dan Koneksi Matematis dalam Konsep Integral. Jurnal Penelitian Pendidikan, 13(1), 44-52. Retrieved from http://jurnal.upi.edu/file/6yani_ramdhana-edi.pdf

Sholihat, N. A. N., Hidayat, W., \& Rohaeti, E. E. (2018). Faktor Kemampuan Penalaran Matematis dan Penghargaan Diri Siswa SMP. JPMI (Jurnal Pembelajaran Matematika Inovatif), 1(1), 1-6.

Sulistiawati, S., Suryadi, D., \& Fatimah, S. (2015). Desain Didaktis Penalaran Matematis untuk Mengatasi Kesulitan Belajar Siswa SMP pada Luas dan Volume Limas. Kreano, $\begin{array}{lllll}\text { Jurnal Matematika } & \text { Kreatif-Inovatif, } & 6(2), & \end{array}$ https://doi.org/10.15294/kreano.v6i2.4833

Sumarmo, U. (2012). Pendidikan karakter serta pengembangan berfikir dan disposisi matematik dalam pembelajaran matematika. Seminar Pendidikan Matematika, 1-26. 